\title{
Instrumentalizacja procesu legislacyjnego w carskiej Rosji i jej wpływ na specyfikę rosyjskiego systemu źródel prawa
}

I. Funkcjonowanie mechanizmu prawodawczego rosyjskiej monarchii absolutnej i związana z nim problematyka źródeł prawa stanowiła i stanowi do dnia dzisiejszego zagadnienie budzące wiele kontrowersji i polemik ${ }^{1}$. Przyczyna tego stanu rzeczy tkwiła w samej istocie rosyjskiego samowładztwa, uniemożliwiającej precyzyjne rozdzielenie sfery władzy ustawodawczej od wykonawczo-zarządzającej, a co za tym idzie, stworzenie jasnego systemu hierarchii źródeł prawa opartych na rozróżnieniu ustawy i rozporządzenia administracyjnego. $Z$ tego względu podejmowane przez rosyjskich teoretyków prawa państwowego i administracyjnego wysiłki w tej mierze z góry skazane były na niepowodzenie. Sytuacja ta nie uległa zmianie nawet po przekształceniach ustrojowych Cesarstwa Rosyjskiego po 1906 r., gdyż dominujące nadal dążenie do zachowania nienaruszalnego zakresu absolutnej władzy monarchy z jednoczesnym tworzeniem pozorów legalizmu jej działania wykluczało w praktyce ustrojowej państwa rosyjskiego możliwość trwałego kompromisu. W konsekwencji, cechą charakterystyczną rosyjskiego prawodawstwa była jego szczególna zawiłość występująca zarówno w odniesieniu do rodzajów i form źródeł prawa, jak i trybu ich stanowienia, możliwość bezkarnego łamania prawa przez wszechwładną biurokrację, oraz dopuszczalność dokonywania zmian w prawie obowiązującym i odstępstw od reguł ogólnych wedle uznania panującego ${ }^{2}$.

${ }^{1}$ Zagadnienie to poruszane było we wszystkich opracowaniach rosyjskiego prawa państwowego. Podsumowanie poglądów na ten temat zawierają prace: W.S. Diakina, Sfiera ukaza i ustawy $w$ trietiejunskoj monarchii, [w:] Wspomagatielnyje istoriczeskije discipliny, t. VIII, Leningrad 1976, s. 236-257, oraz A.W. Riemniewa, Probliema ukaza i zakona w porieformiennoj Rossiji, [w:] Wspomagatielnyje istoriczeskije discipliny, t. XVIII, Leningrad 1987, s. 175-189.

${ }^{2}$ Najdobitniej pogląd ten wyraził Nikołaj A. Zacharow: „(...) nasza konstytucja ograniczyła przede wszystkim samo pojecie ustawy, ale nie swobodne wyrażenie woli władzy najwyższej, a zatem to nie ustawa ale, ale właśnie ukaz jest podstawowym źródłem prawa rosyjskiego", N.A. Zacharow, Sistiema russkoj gosudarstwiennoj własti, Nowoczerkassk 1912, s. 286. 
II. Do początku XX w. jedynym organem ustawodawczym dla Cesarstwa Rosyjskiego był cesarz - samowładny i nieograniczony monarcha absolutny. Jego wola wystarczała do powstania aktu prawnego powszechnie obowiązującego i była wyłącznym źródłem jego mocy wiążącej. Instytucjonalną formą rosyjskiego absolutyzmu stało się - specyficzne tylko dla tego kraju - pojęcie monarchii „samodzierżawnej”. Art. 1. „Praw Zasadniczych Cesarstwa Rosyjskiego” stanowił: „Imperator Wszechrosyjski jest monarchą samodzierżawnym i nieograniczonym. Posłuszeństwo należne Jego władzy najwyższej nakazuje sam Pan Bóg, nie tylko ze względu na strach, ale także ze względu na sumienie"3. Definicja rosyjskiej „monarchii samodzierżawnej” pozostała aktualna także w nowej redakcji „Praw Zasadniczych”, wydanych w 1906 r., głosząc w art. 4, że: „Imperator Wszechrosyjski sprawuje Najwyższą Władzę Samodzierżawną. Podporządkowanie się Jego woli wynika nie tylko z groźby strachu, ale ze względu na sumienie, które nakazuje sam Bóg"4.

Pod pojęciem „samodzierżawie” w nauce rosyjskiej rozumiano zarówno suwerenność zewnętrzną państwa jak i nieograniczoną i niepodzielną władzę cesarza, uprawnionego do bezpośredniej, osobistej ingerencji w stosunkach wewnątrzpaństwowych, działającego w sposób arbitralny i pozbawiony jakichkolwiek form kontroli. Oznaczało to, że cesarz był zarówno źródłem i zwierzchnikiem wszelkich władz państwowych, jak i to, że w wykonywaniu swej władzy nie był związany żadnymi - nawet ustanowionymi przez siebie normami prawnym i żaden akt jego władzy nie wymagał stanowczego współudziału innego organu ${ }^{5}$. Stało to w oczywistej sprzeczności z deklarowaną w art. 47. „Praw Zasadniczych” zasadą praworządności, zgodnie z którą: „Im-

${ }^{3}$ Swod Osnownych Gosudarstwiennych Zakonow (dalej Osnownyje Zakony), izdanije 1832, Swod Zakonow, izdanije 1832, t. I. cz. I, Sankt Petersburg 1835, s. 3, art. 1; Osnownyje Zakony, izdanije 1892, Swod Zakonow, izdanije 1892, t. I. cz. I, Sankt Petersburg 1892, s. 1, art. 1.

${ }^{4}$ Osnownyje Zakony, izdanije1906, Swod Zakonow, izdanije 1912, t. I, cz. I, Sankt Petersburg 1912, s. 1, art. 4.

${ }^{5}$ Wybitny działacz państwowy i kodyfikator Michaił M. Sperańskij, stwierdzał: „(...) Słowo »samodzierżawny« oznacza to, że żadna inna władza na ziemi, władza faktyczna i legalna, ani na zewnątrz ani wewnątrz Imperium, nie może stanowić ograniczenia władzy Samowładcy Rosyjskiego", M.M. Speranskij, Rukowodstwo k poznaniu zakonow, Sankt Petersburg 1845, s. 4. Jeszcze u schyłku XIX w. uczony rosyjski Aleksandr D. Gradowskij twierdził: ,(...) Samodzierżawna władza imperatora rosyjskiego nie jest ograniczona przez normy prawne, które miałyby większą moc niż jego wola", A.D. Gradowskij, Naczała russkogo gosudarstwiennogo prawa, Sankt Petersburg 1875, s. 1-2. Po wydaniu nowej redakcji Praw Zasadniczych z 1906 r., nowoczesną treść pojęciu „samodzierżawie” próbował nadać czołowy rosyjski konstytucjonalista tamtych czasów Nikołaj M. Korkunow, który sprowadzał je wyłącznie do synonimu suwerenności Cesarstwa Rosyjskiego na arenie międzynarodowej: „(...) Wobec obowiązywania Praw Zasadniczych, monarcha rosyjski jest monarchą ograniczonym, lub inaczej - monarchą konstytucyjnym, a państwowy ustrój Rosji jest ustrojem monarchii ograniczonej - lub inaczej monarchii konstytucyjnej. W takich warunkach zasada samodzierżawnej monarchii rosyjskiej powinna być interpretowana jako wyrażająca suwerenność międzynarodową państwa”, N.M. Korkunow, Russkoje gosudarstwiennoje prawo, t. I, Sankt Petersburg 1908, s. 210-222. Jak wykazał Leszek Jaśkiewicz, ta, formułowana w sposób zgodny z kierunkiem przekształceń państwa rosyjskiego w monarchię ograniczoną, wykładnia podstawowej zasady ustrojowej Imperium, stawała w oczywistej sprzeczności z praktyką państwo- 
perium Rosyjskie rządzi się w oparciu o niewzruszone zasady stanowionych praw, statutów i organizacji od Władzy Samodzierżawnej pochodzących"6. Zasada praworządności w postaci przyjętej w Cesarstwie Rosyjskim wiązała więc wszystkie organy państwowe z wyjątkiem cesarza, który mógł działać i postanawiać odmiennie, niż głosiły to stanowione przez niego normy prawne.

$\mathrm{Z}$ istoty rosyjskiego samodzierżawia wynikało, że cała zwierzchnia władza państwowa spoczywała w osobie cesarza, zaś jej wykonywanie należało bezpośrednio do monarchy lub uprawnionych przez niego organów. Wykluczało to możliwość formalnego podziału organów państwa na ustawodawcze i wykonawcze. W warunkach ustroju państwa rosyjskiego można było mówić jedynie o podziale funkcji na ustawodawcze i wykonawcze, przy czym podział ten zależał wyłącznie od woli cesarza - dzierżyciela pełni zwierzchniej władzy państwowej. Z tego względu prawodawstwo rosyjskie posługiwało się pojęciem „zarządu zwierzchniego” (wierchownoje uprawlenije) lub „administracji centralnej”, oraz „zarządu podporządkowanego” (podczinnienoje uprawlenije) lub ,administracji podporządkowanej”, które to pojęcia obejmowały zarówno stanowienie prawa jak i wszystkie akty wykonawczo-administracyjne. Istota pierwszego polegała na bezpośrednim sprawowaniu władzy przez cesarza osobiście lub przy udziale upoważnionych przez niego organów takich jak Rada Państwa, Komitet Ministrów czy Senat Rządzący; drugiego na delegowaniu określonych kompetencji monarszych do samodzielnego rozstrzygania pewnych spraw wskazanym przez niego organom, np. ministrom, gubernatorom i instytucjom samorządowym. W konsekwencji powstał swoisty tylko dla państwa rosyjskiego podział źródeł prawa nie tyle ze względu na formę czy treść aktu prawnego, ile ze względu na tryb legislacyjny, w którym doszedł on do skutku. Stąd też tak w prawodawstwie jak i w teorii rosyjskiego prawa państwowego, akty prawne dzielono na stanowione w trybie administracji centralnej i stanowione w trybie administracji podporządkowanej. Pierwsze realizowane były przy osobistym udziale cesarza, drugie, przez uprawnione przez niego organy?

Do 1906 r. nie istniał w Cesarstwie Rosyjskim żaden formalny podział kompetencji prawodawczych monarchy i podległych mu organów i instytucji

wą schyłkowego okresu istnienia Cesarstwa, L. Jaśkiewicz, Absolutyzm rosyjski w dobie rewolucji 1905-1917, Warszawa 1982, passim.

${ }^{6}$ Osnownyje Zakony, izdanije 1832..., s. 18, art. 47; Osnownyje Zakony, izdanije 1892..., s. 11, art. 47.

${ }^{7}$ „Władza administracyjna w całym zakresie należy wyłącznie do Monarchy. W administracji centralnej Jego władza ma charakter bezpośredni, natomiast w sprawach administracji podporządkowanej Monarcha przekazuje określone kompetencje władcze organom i funkcjonariuszom działającym w Jego imieniu i na Jego rozkaz”. „Przedmiot administracji podporządkowanej, sposób jej funkcjonowania i granice powierzonej jej władzy we wszystkich w ustanowionych organach i instytucjach państwowych, zarówno wyższych jak i niższych im podporządkowanych, są szczegółowo określone w statutach i regulaminach tych organów i instytucji”, Osnownyje Zakony, izdanije $1832 \ldots$, s. 31, art. 80 i 81; Osnownyje Zakony, izdanije 1892..., s. 20, art. 80 i 81. 
państwowych. W praktyce do osobistej decyzji cesarza należało: stanowienie ustaw, tj. praw ogólnych, powszechnie obowiązujących - zwyczajnych i czasowych, wydawanie rozporządzeń nadzwyczajnych, tj. nieopartych na ustawie, zatwierdzanie budżetu państwa, ustalanie organizacji i etatów organów państwowych, ustanawianie, zmiana i znoszenie podatków, podejmowanie decyzji o wywłaszczeniu na cele publiczne oraz ustalanie ostatecznej wysokości odszkodowania w takich wypadkach, postanowienia o zastosowaniu kary konfiskaty majątku, nadawanie i pozbawianie szlachectwa, tytułów honorowych, przyznawanie orderów, nadawanie przywilejów stanom, osobom prywatnym i korporacjom, zarządzenie stanu wojennego, stanu oblężenia i stanu wzmocnionej ochrony oraz stosowanie prawa dyspensy, tj. decydowania $\mathrm{w}$ indywidualnych sprawach $\mathrm{w}$ sposób odmienny niż wskazany w ustawie ${ }^{8}$.

Po wydarzeniach rewolucyjnych 1905 r. władza ustawodawcza cesarza uległa ograniczeniu. W nowej redakcji „Praw Zasadniczych” z 23 IV/ 6 V 1906 r., stanowiących odtąd swoistą konstytucję Cesarstwa Rosyjskiego, wprowadzono zasadę, że monarcha stanowi prawo przy udziale ciał przedstawicielskich - Rady Państwa i Dumy Państwowej - pełniących rolę organu parlamentarnego ${ }^{9}$. Od tej pory inicjatywa ustawodawcza przysługiwała zarówno cesarzowi jak i Radzie oraz Dumie Państwowej, a każda nowa ustawa wymagała zgodnej uchwały obu tych organów oraz sankcji monarszej. Pozornie więc władza ustawodawcza cesarza i obu ciał przedstawicielskich zostały ze sobą zrównane, jednak zastrzeżenie prawa sankcji tylko dla monarchy dawało mu uprzywilejowana pozycję wobec obu izb parlamentarnych. Ponadto, skład osobowy Rady Państwa, traktowanej jako izba wyższa rosyjskiego parlamentu zachował w części charakter biurokratyczny, gdyż połowa jej członków pełniła swoje funkcje z nominacji panującego ${ }^{10}$.

Drugie ograniczenie władzy ustawodawczej cesarza wynikało z nadania „Prawom Zasadniczym” z 1906 r. charakteru norm nadrzędnych wobec wszystkich pozostałych aktów prawnych w państwie. Ustawy wydane bez zachowania właściwego trybu legislacyjnego, przewidzianego w „Prawach Zasadniczych” nie podlegały ogłoszeniu, a więc nie nabierały mocy obowią-

${ }^{8}$ A.D. Gradowskij, op. cit., s. 143-152; W.W. Iwanowskij, Russkoje gosudarstwiennoje prawo, Kazań 1895, s. 85; N.M. Korkunow, Russkoje gosudarstwiennoje prawo, t. II, Sankt Petersburg 1908, s. 12-31; P.E. Kazanskij, Włast' Wsierossijskogo Imperatora, Odessa 1913, s. 54-66; N.A. Zacharow, Sistiema russkoj gosudarstwiennoj własti, Nowoczerkassk 1912, s. 280-301.

9 „Monarcha Imperator jest przedstawicielem władzy ustawodawczej w jedności z Radą Państwa i Dumą Państwową”. ,Żadna nowa ustawa nie może być uchwalona bez aprobaty Rady Państwa i Dumy Państwowej ani nabrać mocy prawnej bez zatwierdzenia przez Imperatora", Osnownyje Zakony, izdanije $1906 \ldots$, s. 1 i 6 , art. 7 i 86.

10 „Rada Państwa składa się z członków mianowanych przez Władzę Najwyższą i członków z wyboru. Ogólna liczba członków Rady mianowanych przez Cesarza nie powinna przewyższać liczby członków Rady pochodzących z wyborów", Osnownyje Zakony, izdanije 1906..., s. 7, art. 100; W.M. Gribowskij, Gosudarstwiennoje ustrojstwo i uprawlenije Rossijskoj Imperii, Odessa 1912, s. 87-92. 
zującej ${ }^{11}$. Jednakże, to do cesarza należała wyłączna inicjatywa zmiany „Praw Zasadniczych”, co w połączeniu z przysługującym mu prawem sankcji wobec uchwał izb parlamentarnych chroniło go przed uszczupleniem dotychczasowych kompetencji zarówno wbrew, jak i bez jego woli ${ }^{12}$.

Pomimo deklarowanej w „Prawach Zasadniczych” z 1906 r. zasady, że ustawodawstwo rosyjskie powstaje w drodze uchwał Dumy i Rady Państwa, sankcjonowanych przez cesarza, ten sam akt prawny pozostawiał do wyłącznej decyzji monarszej szereg kwestii prawodawczych, rozstrzyganych przez niego bez udziału i kontroli izb parlamentarnych.

Do kategorii takiej należały:

1. sprawy dotyczące organizacji administracji państwowej,

2. ustawodawstwo wojskowe,

3. wprowadzanie stanu wyjątkowego i wojennego,

4. nagrody, odznaczenia i tytuły honorowe,

5. tzw. ,ustawodawstwo ukazowe z konieczności”, realizowane w czasie przerw pomiędzy sesjami izb parlamentarnych ${ }^{13}$.

Dopełnieniem samodzielnego ustawodawstwa monarszego było zastrzeżenie wyłącznie do jego kompetencji wykładni autentycznej obowiązujących norm prawnych, nie wyłączając „Praw Zasadniczych”, wraz z prawem do rozwijania i uzupełniania własnymi decyzjami obowiązujących aktów prawnych w sytuacji; ,gdy prawa i instytucje okazują się niedostateczne"14.

Sumując, po 1906 r. ustrój Rosji przybrał kształt monarchii ograniczonej, w której należąca do monarchy władza stanowienia prawa została jedynie częściowo uzupełniona współuczestnictwem Dumy Państwowej i Rady Państwa. „Prawa Zasadnicze” w brzmieniu z 1906 r. ograniczyły cesarza rosyjskiego nie tyle $\mathrm{w}$ zakresie, ile $\mathrm{w}$ sposobie wykonywania niektórych funkcji ustawodawczych. Co prawda, każdy akt ustawodawczy cesarza wymagał odtąd kontrasygnaty prezesa Rady Ministrów lub właściwego ministra, ale nie rodziło to odpowiedzialności ministrów wobec parlamentu. Dumie i Radzie Państwa przysługiwało $\mathrm{w}$ takich wypadkach jedynie prawo interpelacji, o ile uważały takie akty za sprzeczne z obowiązującymi ustawami, ale i one nie niosły za sobą żadnych skutków politycznych czy prawnych, gdyż ministrowie byli odpowiedzialni jedynie przed cesarzem ${ }^{15}$. Zatem „Prawa Zasadni-

11 „Postanowienia prawa nie podlegają ogłoszeniu jeżeli ich tryb wydania był niezgodny z postanowieniami niniejszych Praw Zasadniczych", Osnownyje Zakony, izdanije 1906..., s. 7, art. 92.

12 „Do Imperatora należy inicjatywa we wszystkich przedmiotach ustawodawczych. Jedynie z jego inicjatywy Ustawy Zasadnicze mogą być przedstawione do rozpatrzenia pod obrady Rady Państwa i Dumy Państwowej”, Osnownyje Zakony, izdanije 1906..., s. 1, art. 8.

${ }^{13}$ Osnownyje Zakony, izdanije 1906..., s. 1-2, 7-9, art. 11-16, 18-19, 23, 96-97, 119 i 125.

${ }^{14}$ Uczrieżdienija Ministierstw, izdanije 1892, Swod Uczrieżdienij Gosudarstwiennych, Swod Zakonow, izdanije 1912, t. I, ks. V, s. 173, art. 174.

15 „Ukazy i rozkazy Cesarza wydawane w trybie zarządu zwierzchniego utwierdzane są przez Prezesa Rady Ministrów lub właściwych ministrów lub głównozarządzających poszczególnymi 
cze" z 1906 r. nie rozstrzygnęły jednoznacznie, czy cesarz pozostaje nadal jedynowładcą a organy przedstawicielskie są wyłącznie jego organami, czy też są reprezentacją społeczeństwa, równorzędną monarsze jako dzierżycielowi najwyższej władzy wykonawczej ${ }^{16}$.

III. Zgodnie z fundamentalną zasadą rosyjskiego samodzierżawia, jedynym prawodawcą był cesarz. Jego wola wystarczała do powstania aktu prawnego powszechnie obowiązującego i była wyłącznym źródłem jego mocy wiążącej ${ }^{17}$. W teorii, spośród stanowionych przez niego lub z jego woli źródeł prawa, wyróżniano ustawy, zarówno z punktu widzenia ich stosunku do innych źródeł prawa, jak i z punktu widzenia trybu legislacyjnego i sposobu publikacji, oraz ukazy, tj. rozporządzenia i postanowienia wykonawcze wydawane na podstawie jego delegacji przez organy administracji podporządkowanej. Odzwierciedlał to schemat: monarcha - wyłączny ustawodawca i podległe mu organy administracyjne, realizujące z jego woli władzę wykonawczą. Ustawa - według terminologii urzędowej „prawo ogólne” - miała stanowić podstawę działania aparatu państwowego ${ }^{18}$.

Ten ideał w warunkach ustrojowych państwa rosyjskiego nigdy nie funkcjonował. W XIX w. praktyka prawodawcza doprowadziła do ustanowienia różnorodnych form wyjawienia woli monarszej, które $\mathrm{z}$ formalnego punktu widzenia były ustawami, ale ich merytoryczna zawartość odpowiadała aktom wykonawczym. W konsekwencji, sfera bezpośredniego działania monarchy nie ograniczała się jedynie do funkcji ustawodawczej, ale obejmowała rów-

częściami zarządu administracyjnego państwa i są ogłaszane przez Senat Rządzący", Osnownyje Zakony, izdanije 1906..., s. 2, art. 24.

${ }^{16}$ Wydaje się, że zwyciężyła pierwsza koncepcja, gdyż już w Manifeście z 18 II/3 III 1905 r. zapowiadającym powołanie Dumy Państwowej, Mikołaj II oficjalnie uznawał konstytucjonalizm i parlamentaryzm zachodnioeuropejski za ,nieodpowiadający naszej ojczyźnie”, Polnoje Sobranije Zakonow Rossijskoj Imperii (dalej PSZRI) 1905, nr 25852, s. 132-133.

17 „Żaden organ ani władza w państwie nie może samodzielnie stanowić nowych praw i żadne prawo nie może zostać ustanowione bez zatwierdzenia go przez Władzę Samodzierżawną", Osnownyje Zakony, izdanije 1832..., s. 19, art. 51; Osnownyje Zakony, izdanije 1892..., s. 12, art. 51.

${ }^{18} \mathrm{~W}$ dziewiętnastowiecznej rosyjskiej terminologii prawniczej nie istniało pojęcie ustawy jako samodzielnego terminu stosowanego dla określenia aktu prawnego powszechnie obowiązującego, ustanowionego w trybie ustawodawczym. Istniał natomiast termin „ustaw”, który w języku polskim oznacza „statut” (np. statut spółki czy stowarzyszenia). W miejsce terminu „ustawa”, w oficjalnej nomenklaturze rosyjskiej posługiwano się szerokim pojęciem „,zakon”, czyli „prawo”, którym obejmowano zarówno akty ustawodawcze jak i wszystkie inne akty prawne. Natomiast w polskiej terminologii prawniczej tego okresu terminem ,ustawa” posługiwano się dla określenia wszystkich aktów prawnych powszechnie obowiązujących, takich jak: prawa - „zakony”, statuty - „ustawy”, jak i organizacje - „uczrieżdienija” i postanowienia - „położenija”. Ten oczywisty brak precyzji w thumaczeniu rosyjskich terminów prawniczych na język polski, występujący powszechnie zarówno w ówczesnych tekstach oficjalnych, takich jak akty prawne, jak i w polskim piśmiennictwie prawniczym, utrzymał się w polskiej literaturze przedmiotu do dziś. Z tego względu w niniejszym opracowaniu zdecydowano się - przy zastrzeżeniu powyższych rozbieżności stosować nomenklaturę aktów prawnych w języku polskim przyjętą w czasach ich obowiązywania na ziemiach polskich. 
nież akty wykonawcze. Potwierdzała to treść art. 53 dwóch pierwszych redakcji „Praw Zasadniczych”:

„Prawa (zakony) stanowione są w formie kodeksów (ułożenij), statutów (ustawow), organizacji (uczreżdienij), gramot, postanowień (położenij), rozkazów (powielenij), instrukcji (nakazow), manifestów (manifiestow), ukazów, zdań Rady Państwa (mnienij Gosudarstwiennogo Sowieta) i raportów (dokładow), wymagających Najwyższego zatwierdzenia. Najwyższe rozkazy (wysoczajszije powielenija) stanowione $\mathrm{w}$ trybie administracyjnym wydawane są ponadto $\mathrm{w}$ formie reskryptów (rieskriptow) i nakazów (prikazow)"19.

Ponadto, stała praktyka delegowania szeregu uprawnień w procesie legislacyjnym organom administracji centralnej stwarzała niespotykaną w innych państwach możliwość manipulowania zgodnie z aktualnymi potrzebami rosyjskiej biurokracji. Zatem, wobec braku granicy pomiędzy ustawą a rozporządzeniem, hierarchiczne podporządkowanie ukazów ustawom nie mogło być realizowane w logiczny sposób. Niezależnie od tego, czy akty prawne były wydawane bezpośrednio przez monarchę, czy też przez podległe mu organy administracji, jednakowo uważane były za realizację władzy należącej do samego panującego.

Szczególną cechą ustroju państwa rosyjskiego była duża liczba organów administracji centralnej, przy udziale których monarcha realizował swe kompetencje prawodawcze. Zaliczano do nich przede wszystkim Radę Państwa, Komitet Ministrów i Senat Rządzący, ale także Święty Synod, Własną J.C.M. Kancelarię, Radę Wojenną, Admiralicję, Komitet Finansów, Komitet do spraw Służby w Rangach Cywilnych, ministrów i kierowników urzędów centralnych oraz utworzoną w 1906 r. Radę Ministrów. W warunkach Królestwa Polskiego rolę taką pełniły w latach 1832-1881: Rada Stanu, komisje rządowe, Komitet do spraw Królestwa Polskiego i Własna J.C.M. Kancelaria do spraw Królestwa Polskiego. Wszystkie te instytucje były organami nie tylko doradczymi cesarza, ale także - każdy w granicach swych kompetencji - prawodawczy$\mathrm{mi}^{20}$. Zachowanie tak dużej liczby organów uprawnionych, obok monarchy, do udziału w procesie legislacyjnym prowadziło do występowania w prawodawstwie rosyjskim mnogości form aktów prawnych stanowionych w trybie administracji centralnej. Najistotniejsze z nich, bo podkreślające osobistą rolę cesarza w sformułowaniu ich treści i publikacji, przybierały formę „manifestów” (manifiest) i „najwyższych ukazów imiennych” (imiennoj wysoczajszij ukaz). W administracji cywilnej najczęściej występowały akty prawne noszące mia-

${ }^{19}$ Osnownyje Zakony, izdanije $1832 \ldots$, s. 21, art. 53; Osnownyje Zakony, izdanije 1892..., s. 13 , art. 53 .

${ }^{20}$ N.M. Korkunow, Russkoje gosudarstwiennoje prawo..., t. II, s. 143-185; W.M. Gribowskij, op. cit., s. 113-128; B.E. Nolde, Oczerki russkogo gosudarstwiennogo prawa, Sankt Petersburg 1911, s. 193; P.E. Kazanskij, op. cit., s. 82. 
no „ukazu najwyższego” (wysoczajszij ukaz), lub „rozkazu najwyższego” (wysoczajsze powielenie), „zdania Rady Państwa” (mnienije Gosudarstwiennogo Sowieta), ,uchwały Komitetu Ministrów” a od 1906 r. „uchwały Rady Ministrów" (wysoczajsze położenije Komitieta Ministrow, wysoczajsze położenije Sowieta Ministrow), „ukazu” lub „postanowienia Senatu Rządzącego” (ukaz, postanowlenije Prawitielstwujuszczago Senata), „opinii Komitetu Finansów” (sużdienije Komiteta Finansow) i ,najwyżej zatwierdzonych raportów ministrów" (wysoczajszije utwierżdiennyja dokłady ministrow), zaś w administracji wojskowej - „najwyżej zatwierdzone rezolucje Rady Wojennej i Admiralicji” (wysoczajszije utwierżdiennyja położenije Wojennogo Sowieta i Admiralicji). W sprawach odnoszących się do administracji kozackiej zachowano archaiczną formę „,gramot”. Ze względu na treść wyróżniano: „prawa” - „ustawy” (zakony), „urządzenia” i „organizacje” (uczreżdienija), „statuty” (ustawy), „regulaminy” (reglamienty), „nakazy” (instrukcije), „reskrypty” (rieskripty) i „kodyfikacje” (ułożenija). Z formalnego punktu widzenia akty te miały jednakową moc prawną, a każdy z nich traktowany był jako najwyższy, nieodwołalny i niepodlegający zaskarżeniu przejaw osobistej woli monarszej ${ }^{21}$.

IV. Do 1906 r. prawo inicjatywy ustawodawczej przysługiwało wyłącznie monarsze ${ }^{22}$. Dopiero po tej dacie takie uprawnienie uzyskały także obie izby parlamentarne, Rada Państwa i Duma Państwowa, ale tylko w kwestiach niezastrzeżonych dla osobistej władzy cesarza. W praktyce akty prawne wydawane w trybie administracji centralnej powstawały także z inicjatywy ministrów, uchwał Senatu, a nawet na skutek petycji organizacji społecznych lub samorządowych wnoszonych do tronu z prośbą o podjęcie prac legislacyjnych w zakresie pożądanych przez nie potrzeb prawodawczych. W tym ostatnim przypadku prawo to przysługiwało samorządowym zgromadzeniom szlacheckim i ziemskim. Ich petycje, choć przedkładane bezpośrednio monarsze, miały wyłącznie charakter niewiążącej cesarza prośby - sugestii, i w żadnym wypadku nie mogły odnosić się do podstawowych kwestii ustroju, organizacji i zakresu funkcjonowania aparatu państwowego ${ }^{23}$.

Do początku XIX stulecia przepisy regulujące proces legislacyjny w $\mathrm{Ce}-$ sarstwie Rosyjskim były nieliczne i na dodatek rozproszone w wielu osob-

${ }^{21}$ B.M. Koczakow, Russkij zakonodatielnyj dokument XIX-XX wiekow [w:] Wspomagatielnyje istoriczeskije discipliny, t. XVIII, Moskwa-Leningrad 1937, s. 319-362.

22 „Wszystkie projekty praw są rozpatrywane w Radzie Państwa, a następnie przekazywane do Najwyższego uznania i nie inaczej są kierowane do ich ustanowienia jak z inicjatywy Władzy Samodzierżawnej.”, Osnownyje Zakony, izdanije 1832..., s. 19, art. 50; Osnownyje Zakony, izdanije $1892 \ldots$, s. 11 , art. 50 .

${ }^{23}$ N.M. Korkunow, Russkoje gosudarstwiennoje prawo..., t. II, s. 491-497; S. Libicki, O wydawaniu praw i ustroju instytucji prawodawczych rosyjskich, Warszawa 1890, s. 22-27. W Królestwie Polskim, gdzie nie istniał samorząd szlachecki ani samorząd ziemski, prawo petycji nie mogło być realizowane. 
nych i niepowiązanych ze sobą aktach prawnych. Sytuacja ta uległa zmianie z chwilą powołania Rady Państwa w 1810 r. i wydania pierwszej redakcji Zwodu Praw w latach 1832-1835 r. Przepisy określające tryb powstawania projektu prawodawczego i wprowadzenia go w życie zostały ujęte w I tomie Zwodu Praw, w tytule VIII Praw Zasadniczych - O zakonach („O prawach”), w 33 artykułach od 47 do 79 włącznie ${ }^{24}$. Określone w nich postępowanie legislacyjne było postępowaniem normalnym, wiążącym wszystkie organy ale nie cesarza, który w swej działalności prawotwórczej nie był skrępowany żadną formą ani żadnym trybem prawodawczym.

W normalnej procedurze przewidzianej w Prawach Zasadniczych dla stanowienia prawa $\mathrm{w}$ trybie administracji centralnej, monarcha $\mathrm{z}$ własnej inicjatywy albo na wniosek Senatu lub Świętego Synodu (w sprawach duchownych wyznania prawosławnego), polecał Radzie Państwa przygotowanie projektu nowego prawa, albo już gotowy projekt, opracowany wcześniej za jego zgodą przez właściwego resortowo ministra lub według jego osobistych wskazówek przez II Oddział Własnej J.C.M. Kancelarii, nakazywał przesłać do zaopiniowania Radzie Państwa ${ }^{25}$. W Radzie projekt rozpatrywany był wstępnie w I lub II departamencie a następnie przedkładano go do ostatecznego zaopiniowania Ogólnemu Zebraniu Rady Państwa. Uchwały Rady Państwa podejmowane były wyłącznie na posiedzeniach plenarnych Ogólnego Zebrania Rady, ale nie wiązały cesarza, który mógł je ignorować. Nosiły one nazwę „Zdania Rady Państwa” (Mnienija Gosudarstwiennogo Sowieta), i po ich przyjęciu przedkładane były do sankcji cesarskiej, która wyrażała się albo przez nakreślenie na ich tekście własnoręcznych słów monarchy Byt' po siemu, albo ustnie i wówczas wola monarchy była komunikowana Radzie przez jej przewodniczącego. Własnoręczny podpis monarchy był wymagany w przypadku:

1. każdego aktu ustawodawczego wprowadzającego nową regulację prawną,

2. ustanowienia lub zniesienia podatków,

3. zatwierdzenia etatów wszystkich zarządów państwowych,

4. zatwierdzenia budżetu państwa,

5. decyzji o wywłaszczeniu na cel publiczny.

${ }^{24}$ Osnownyje Zakony, izdanije 1832, razdieł I: O prawach Wierchownoj Własti, gława VIII; O zakonach ..., s. 18-30, art. 47-81. Te same artykuły w identycznym brzmieniu znalazły się w kolejnej redakcji Praw Zasadniczych z 1892 r., Osnownyje Zakony, izdanije 1892, razdieł I: O prawach Wierchownoj Własti, gława VIII; O zakonach..., s. 11-20, art. 47-81.

${ }^{25}$ „Pierwotny projekt prawa przygotowywany jest albo na podstawie bezpośredniego rozkazu Cesarza, albo wynika z ogólnego biegu spraw, jeżeli podczas rozpatrywania w Senacie Rządzącym, Świętym Synodzie i w ministerstwach uznane zostanie za konieczne wyjaśnienie i uzupełnienie prawa obowiązującego albo sporządzenie nowych przepisów. W takim wypadku wyżej wymienione organy przekazują ich projekty w przewidzianym prawem trybie do Najwyższego rozpatrzenia", Osnownyje Zakony, izdanije 1832..., s. 18-19, art. 49; Osnownyje Zakony, izdanije 1892..., s. 11, art. 49 . 
Sankcjonowane przez cesarza projekty praw w formie „Zdania Rady Państwa” przybierały postać „Ukazów najwyższych”, które przesyłano Senatowi Rządzącemu celem ich publikacji i wykonania ${ }^{26}$.

Od tej procedury znano jednak liczne wyjątki, prowadzące do powstania aktu prawnego w trybie administracji centralnej z pominięciem Rady Państwa. Przede wszystkim, cesarz jako jedyny ustawodawca miał możliwość stanowienia prawa bez konieczności zwracania się do Rady Państwa o opinię, pod warunkiem że przybierze ono formę manifestu lub ukazu imiennego do Senatu Rządzącego, opatrzonego własnoręcznym podpisem monarchy i odciskiem wielkiej pieczęci państwowej ${ }^{27}$. W praktyce prawo stanowione $\mathrm{w}$ formie manifestów występowało stosunkowo rzadko - najczęściej w okresie reform lub zaburzeń wewnętrznych. Jego cechą charakterystyczną było to, że oprócz nowej regulacji prawnej zawierało zwykle deklaracje polityczne, wyznaczające aktualny kierunek działania aparatu państwowego. Zdecydowanie liczniejsze ukazy imienne były natomiast wynikiem prawotwórczej działalności wyższej biurokracji rosyjskiej, tj. ministrów ${ }^{28}$.

Pomimo deklarowanej w Prawach Zasadniczych zasady, że wszystkie projekty prawodawcze rozpatrywane są w Radzie Państwa, z treści art. 53 wynikało jednoznacznie, że nowe prawa mogą powstawać także na podstawie przedłożeń ministrów, które uzyskały sankcję cesarską. Praktyka ujęła to w postaci „najuniżeńszych raportów ministrów” (wsiepoddanniejszije otczety ministrow), składanych bezpośrednio monarsze, które w swojej treści zawierały projekt nowego prawa wraz z prośbą o wprowadzenie go w życie. Cesarz mógł zaaprobować taki raport ministra w formie byt'po siemu, sogłasien lub priniat' $k$ rukowodstwu bez odsyłania go do rozpatrzenia w Radzie Państwa i skierować do Senatu Rządzącego „Najwyższy rozkaz” nakazujący jego ogłoszenie i wykonanie. Wydany w ten sposób ukaz nosił nazwę „Najwyżej Zatwierdzonego Ukazu na Imię Ministra" (Wysoczajszij Utwierżdionnyj Ukaz na Imia Ministra $)^{29}$.

${ }^{26}$ Procedurę tę regulowały art. 77-95 Organizacji Rady Państwa z 1832 r., którym odpowiadały art. 52-86 Organizacji Rady Państwa z 1892 r., Uczrieżdienije Gosudarstwiennogo Sowieta, izdanije 1832, Swod Uczrierżdienij Gosudarstwiennych, Swod Zakonow, izdanije 1832, t. I, cz I, ks. I, s. 81-86, art. 77-95; Uczrieżdienije Gosudarstwiennogo Sowieta, izdanije 1892, Swold Uczrieżdienij Gosudarstwiennych, Swod Zakonow, izdanije 1892, T. I, cz. II, ks. I, s. 11-15, art. 52-86.

${ }^{27}$ B.M. Koczakow, op. cit., s. 322.

${ }^{28}$ Przyczyniało się to do wyraźnego osłabienia znaczenia Rady Państwa w systemie organów prawodawczych Cesarstwa, co krytykował Aleksandr D. Gradowskij, pisząc: „(...) Jeżeli istnieje w obecnych czasach instytucja, której działalność jest mało dostrzegalna, to jest to właśnie Rada Państwa. Jeżeli istnieje instytucja, którą należy koniecznie ożywić, to jest to właśnie ta sama Rada Państwa”, A.D. Gradowskij, Gosudarstwiennyj Sowiet, [w:] Sobranije soczinienij, Sankt Petersburg 1903 , t. 8 , s. 513.

${ }^{29}$ Do drugiej połowy XIX w. nie było wyraźnie określonej formy aprobaty cesarskiej przewidzianej dla ukazu powstałego taką drogą legislacyjną. W praktyce sankcja cesarska mogła przybierać zarówno formę pisemną jak i ustną. Dopiero Najwyżej Zatwierdzone Zdanie Rady Państwa z 5/17 XI 1885 r. o porządku kodyfikacji w Zwodzie Praw Cesarstwa Rosyjskiego, wydane na 
Inną drogą stanowienia prawa w trybie administracji centralnej bez udziału Rady Państwa były uchwały Komitetu Ministrów. Pomimo że formalnie Komitet nie był wyposażony w kompetencje prawodawcze, to zgodnie $\mathrm{z}$ art. 176 jego organizacji, oprócz zagadnień bieżących, wynikających z jego działalności jako organu zarządzająco-administracyjnego, był również uprawniony do rozstrzygania wszystkich spraw wniesionych pod jego obrady przez cesarza $^{30}$. W rezultacie szybko pojawiła się powszechna praktyka, że minister, który zamierzał doprowadzić do wydania nowego prawa lub zmiany już istniejącego z pominięciem Rady Państwa, zwracał się bezpośrednio do cesarza o wniesienie jego projektu ustawodawczego pod obrady Komitetu Ministrów a nie Rady Państwa. W takiej sytuacji projekt ministra, za zgodą cesarza, był rozpatrywany przez Komitet Ministrów, który podejmował w jego przedmiocie uchwałę zwykłą większością głosów, wpisywaną następnie do Dziennika Komitetu Ministrów (Żurnat Sowieta Ministrow) ${ }^{31}$. Podpisane przez cesarza i ogłoszone przez Senat uchwały Komitetu Ministrów, nosiły nazwę „Najwyżej Zatwierdzonych Uchwał Komitetu Ministrów" (Wysoczajsze Utwierżdiennoje Położenije Komiteta Ministrow), stając się kolejnym źródłem prawa administracyjnego w Cesarstwie Rosyjskim, obowiązującym na równi z ukazami najwyższymi, z tym że ich wykonanie powierzano właściwemu resortowo ministrowi, a nie Senatowi Rządzącemu ${ }^{32}$.

W konsekwencji, wśród różnych dróg prawodawczych, przewidzianych dla stanowienia prawa w trybie administracji centralnej, minister mógł wybrać dla siebie najdogodniejszą, szybko osiągając zamierzony cel bez ryzyka narażenia się na krytykę podczas dyskusji w Radzie Państwa. Najłatwiej można był to osiągnąć poprzez „,najuniżeńszy raport” składany bezpośrednio cesarzowi albo wnosząc projekt nowego prawa pod obrady Komitetu Mini-

wniosek przewodniczącego Departamentu I Rady Państwa E.W. Frisza, zastrzegło w takich przypadkach konieczność osobistego podpisu monarchy, PSZRI 1885, nr 3261, s. 447-449, art. 1-16; B.M. Koczakow, op. cit., s. 324.

${ }^{30}$ Postanowienie art. 174 Organizacji Komitetu Ministrów zastrzegało, że: „Do Komitetu nie powinny być wnoszone projekty w sprawach należących do kompetencji Rady Państwa i Senatu Rządzącego", a art. 176 stanowił, że: „Żadna sprawa nie może być rozpatrywana w Komitecie inaczej jak na wniosek ministrów lub na podstawie Rozkazu Najwyższego", Uczrieżdienije Komitieta Ministrow, izdanije 1832, Swod Uczrieżdienij Gosudarstwiennych, Swod Zakonow, izdanije 1832, t. I, cz. I, ks. II, s. 101, art. 174 i 176; Uczrieżdienije Komitieta Ministrow, izdanije 1892, Swod Uczrieżdienij Gosudarstwiennych, Swod Zakonow, izdanije 1892, t. I, cz. II, ks. II, s. 8-9, art. 29 i 30.

${ }^{31}$ Procedurę w takich przypadkach regulowały art. 181-207 Organizacji Komitetu Ministrów z 1832 r., którym odpowiadały art. 36-65 Organizacji Komitetu Ministrów z 1892 r., Uczrieżdienije Komitieta Ministrow, izdanije 1832 ..., s. 102-106, art. 181-207; Uczrieżdienije Komitieta Ministrow, izdanije $1892 \ldots$, s. 9-13, art. 36-65.

${ }^{32}$ W związku z tym Aleksandr D. Gradowskij wskazywał, że: „(...) Komitet Ministrów jest to instytucja dająca ministrom możliwość wprowadzania ważnych przepisów z mocą ustawy obok Rady Państwa i obywać się w sprawach wykonawczych bez kontroli Senatu Rządzącego, co stanowi przeszkodę w ustanowieniu jednolitej drogi ustawodawczej, A.D. Gradowskij, Komitiet Ministrow, Sobranije soczinienij..., t. 8, s. 521. 
strów ${ }^{33}$. Sytuacja ta nie uległa zmianie po przekształceniu w 1905 r. Komitetu Ministrów w Radę Ministrów, która utrzymała prawo podejmowania uchwał w sprawach prawodawczych (nosiły one teraz nazwę „Najwyżej Zatwierdzonych Uchwał Rady Ministrów" [Wysoczajsze Utwierżdiennoje Położenije Sowieta Ministrow]. Ponadto, pomimo utworzenia kolegialnego organu władzy wykonawczej, poszczególni ministrowie nadal zachowali prawo składania sprawozdań bezpośrednio carowi, bez uprzedniego rozpatrzenia ich w Radzie Ministrów. Przedłożenia takie, po nadaniu im sankcji cesarskiej, zachowały dotychczasową formę ,ukazów najwyższych na imię ministra"34.

Szczególną formą stanowienia prawa w trybie administracji centralnej było tzw. „ustawodawstwo odrębne” (sieparatnoje zakonodatielstwo), z założenia realizowane bezpośrednio przez cesarza lub upoważnione przez niego organy, z pominięciem udziału Rady Państwa. Przybierało ono postać dyspensy lub przywileju polegającego na decydowaniu w sprawach jednostkowych w sposób odmienny od przewidzianego $\mathrm{w}$ obowiązujących przepisach pra$\mathrm{wa}^{35}$. Istotą przywileju była zgoda na odstępstwo od przyjętych powszechnie reguł w stosunku do konkretnej, zindywidualizowanej sytuacji prawnej osoby prywatnej, zaś prawo dyspensy pozwalało na uchylenie mocy obowiązującej poszczególnych przepisów prawnych w sprawach jednostkowych lub jednorodnych bez względu na charakter podmiotu. W konsekwencji, ustawodawstwo odrębne stwarzało możliwość tworzenia nowych przepisów prawnych bez względu na to, czy w takich sprawach istniała już ogólna regulacja prawna czy też nie ${ }^{36}$.

Realizacja ustawodawstwa odrębnego przez cesarza następowała zarówno z jego inicjatywy, jak i na wniosek zainteresowanego ministra, a nawet na skutek prośby osoby prywatnej lub stowarzyszenia. W takich przypadkach

${ }^{33}$ Otwarcie wyraził to minister spraw wewnętrznych Nikołaj P. Ignatiew w rozmowie z sekretarzem Rady Państwa E.A. Pieretcem, który zarzucił mu, że forsuje swoje projekty prawodawcze z pominięciem Rady Państwa: „(...) nie jeździłem i nie będę jeździł do Rady Państwa. Powiem więcej, nie będę przedstawiał projektów Radzie Państwa, a będę je wnosił do Komitetu ministrów. Możecie powiedzieć, że to jest niezgodne z prawem. Być może. Ale mimo wszystko, w razie potrzeby można zwrócić się do Komitetu z wnioskiem o zatwierdzenie projektu jako regulacji tymczasowej (...)", cyt. za: A.W. Riemniew, Probliema ukaza i zakona w porieformiennoj Rossiji..., s. 132.

${ }^{34}$ Do przedłożeń ministrów należą szczególnie: ogłoszone Najwyższe Ukazy na Imię Ministra (...), Uczrieżdienija Ministierstw, izdanije 1892, Swod Uczrieżdienij Gosudarstwiennych, Swod Zakonow, izdanije 1892, t. I, cz. II, s. 168, art. 108.

35 „Ukaz Najwyższy wydany w konkretnej sprawie lub też specjalnie dla jakiegoś rodzaju spraw, uchyla obowiązywanie praw ogólnych w danej sprawie lub dla danego rodzaju spraw", Osnownyje Zakony, izdanije 1832..., s. 27, art. 70; Osnownyje Zakony, izdanije 1892..., s. 18, art. 70.

36 „Przywileje nadane przez Najwyższą Władzę Samodzierżawną konkretnym osobom lub grupom osób, wyłączają je spod mocy obowiązującej praw ogólnych w tych kwestiach, których dotyczą określone przepisy, zawarte w owych przywilejach", Osnownyje Zakony, izdanije 1832..., s. 27-28, art. 71; Osnownyje Zakony, izdanije $1892 \ldots$, s. 18, art. 71. Prawo dyspensy stosowano np. wobec rodów arystokratycznych, zwalniając Polaków z zakazu nabywania majątków ziemskich na Ukrainie, Z. Kotiużyński, Pamiętniki, Kraków 1919, s. 116. 
monarcha albo osobiście wydawał „Najwyższe Polecenie” (Wysoczajsze Powielenie) i kierował je bezpośrednio do Senatu Rządzącego celem publikacji, albo na wniosek ministra upoważniał Komitet Ministrów do rozpatrzenia takiej sprawy i podjęcia stosownej uchwały ${ }^{37}$. „Rozkazy Najwyższe” jak i „Najwyżej Zatwierdzone Uchwały Komitetu Ministrów” wydane w drodze ustawodawstwa odrębnego podlegały jednak ściślejszym rygorom formalnym niż ukazy zwyczajne. Stosowanie prawa dyspensy bezpośrednio przez cesarza musiało nastąpić w formie pisemnej i zawierać precyzyjne określenie, czy dotyczy tylko danej konkretnej sytuacji, czy też stanowi odtąd regułę ogólną we wszystkich sprawach takiego rodzaju. W razie wątpliwości powstałych na tle stosowania prawa stanowionego $\mathrm{w}$ drodze ustawodawstwa odrębnego, prawo wykładni autentycznej należało wyłącznie do cesarza ${ }^{38}$.

Po 1906 r. ustawodawstwo odrębne zostało w znaczący sposób ograniczone. Zgodnie z art. 94 nowej redakcji Praw Zasadniczych, monarcha utracił prawo dyspensy, a więc prawo samodzielnego decydowania ukazami najwyższymi o odstępstwie od ogólnej regulacji ustawowej według własnej woli, a więc bez delegacji ustawowej ${ }^{39}$. Jednak ten sam akt prawny pozostawiał wyłącznej decyzji cesarskiej sprawy dotyczące organizacji administracji państwowej, ustawodawstwo wojskowe, wprowadzanie stanu wojennego, nagrody, odznaczenia i tytuły honorowe oraz wspomniane wcześniej tzw. „ustawodawstwo ukazowe z konieczności”, realizowane w czasie przerw pomiędzy sesjami izb parlamentarnych. Istotną nowością było to, że postanowienia cesarskie $\mathrm{w}$ takich sprawach nie mogły już być sprzeczne $\mathrm{z}$ ogólną regulacją ustawową ${ }^{40}$.

Pomimo że Prawa Zasadnicze z 1906 r. nie przewidywały prawa dyspensy, w praktyce było ono realizowane nadal przez Radę Ministrów, która przejęła w tym zakresie kompetencje Komitetu Ministrów. Zgodnie z art. 174 Regulaminu Ministerstw, zezwalającym na przedkładanie sprawy cesarzowi w przypadkach, ,gdy ustawy i regulaminy są niewystarczające”, Rada Ministrów mogła podjąć uchwałę o indywidualnej regulacji prawnej w sprawach

37 W szczególności do takich spraw należały: indywidualne sprawy urzędników (nagrody, emerytury), sprawy związane z utrzymaniem spokoju i bezpieczeństwa publicznego oraz wszystkie sprawy, których rozwiązanie przekraczało granice władzy powierzonej poszczególnym ministrom i z tego względu wymagały decyzji cesarza, Uczrieżdienije Komitieta Ministrow, izdanije $1832 \ldots$, s. 100, art. 173; Uczrieżdienije Komitieta Ministrow, izdanije 1892..., s. 6, art. 26.

38 „Tzw. „ukaz odrębny”, tj. uchwalony w konkretnej sprawie, nie posiada mocy ustawy, jeżeli nie jest w nim dokładnie stwierdzone, że ma zastosowanie do podobnych przypadków w przyszłości, a także, jeśli nie został ogłoszony w prawem przewidzianym trybie”, Osnownyje Zakony, izdanije $1832 \ldots$, s. 27, art. 67; Osnownyje Zakony, izdanije 1892..., s. 17, art. 67.

39 „Ustawa może być uchylona jedynie inną ustawą. Dlatego, dopóki nowa ustawa wyraźnie nie uchyli ustawy dotychczas obowiązującej, zachowuje ona swą moc prawną w pełnym zakresie", Osnownyje Zakony, izdanije 1906..., s. 7, art. 94.

40 „Monarcha, w trybie administracji centralnej, wydaje zgodnie z ustawami, ukazy dotyczące tworzenia i wprowadzania w życie różnorodnych części administracji państwowej, a także rozkazy niezbędne do realizacji tych ustaw”, Osnownyje Zakony, izdanije 1906..., s. 6-7, art. 87. 
statutów spółek akcyjnych, wysokości rent i emerytur, jak i we wszystkich sprawach przekraczających kompetencje pojedynczego ministra ${ }^{41}$. Możliwość stosowania prawa dyspensy w takich przypadkach była dopuszczalna jedynie w sprawach przewidzianych ustawą. Natomiast dawne prawo Komitetu Ministrów, które dawało możliwość stosowania dyspensy również w sprawach nieprzewidzianych ustawą, zostało formalnie zniesione. W rzeczywistości było jednak inaczej. Jak pisał obserwator ówczesnej biurokracji rosyjskiej:

„(..) istnieje nadal prawie codzienna praktyka najuniżeńszych raportów ministrów we wszystkich resortach, w których przeważnie uzyskuje się odstępstwa od regulacji ustawowych, których mocy nikt nie kwestionuje. Jak widać, wpływ nowych regulacji ustępuje tradycji historycznej" ${ }^{42}$.

V. Realizacja podstawowej zasady ustrojowej państwa rosyjskiego, zgodnie z którą stanowienie prawa należy bezpośrednio do monarchy, a jedynie wyjątkowo także do upoważnionych przez niego organów, znalazła teoretyczne odzwierciedlenie $\mathrm{w}$ pojęciu administracji podporządkowanej. Do tej kategorii zaliczano organy, które na podstawie osobistego pełnomocnictwa cesarza lub delegacji ustawowej (co do $1906 \mathrm{r}$. w praktyce oznaczało to samo), uprawnione były do ograniczonego, ale samodzielnego decydowania w sprawach przekazanych do ich kompetencji, o ile monarcha nie postanowił inaczej i nie podjął decyzji osobiście ${ }^{43}$. W praktyce reguła, według której monarcha zachowywał monopol na stanowienie prawa i warunkowo delegował takie uprawnienie wskazanym przez siebie organom uległa w ciągu XIX w. przekształceniu $\mathrm{w}$ generalne pełnomocnictwo wydawania aktów prawnych w trybie administracji podporządkowanej, udzielane zarówno organom cen-

${ }^{41}$ „W przypadkach gdy statuty i regulaminy są niewystarczające lub gdy wymagają one bezpośredniej rozstrzygnięcia lub postanowienia Władzy Najwyższej, sprawy takie przedkładane są Władzy Najwyższej za pośrednictwem Rady Ministrów", Uczrieżdienija Ministerstw, izdanije $1892 \ldots$, s. 173 , art. 174.

42 A.I. Jelistratow, Osnownyje naczała russkago administratiwnogo prawa, Moskva 1914, s. 137.

43, „(...) W celu rzeczywistego wypełnienia rozkazów władzy najwyższej tworzone są powołane do działania na podstawie jego pełnomocnictwa i zgodnie ze wskazówkami organów administracji centralnej organy administracji podporządkowanej. Organy te nie mogą działać w żaden inny sposób jak tylko na podstawie pełnomocnictwa zawartego w ustawie lub osobistym poleceniu cesarza”. „(...) Administracja podporządkowana występuje jako realizacja nie tyle nieograniczonej władzy państwowej, lecz jako realizacja ograniczonych pełnomocnictw wydawanych przez organy administracji centralnej. Administracja podporządkowana, podobnie jak i centralna, nie posiada ogólnego pełnomocnictwa do kierowania państwem, posiada natomiast jedynie pełnomocnictwo do realizacji określonych zadań administracji w granicach określonych w aktach administracji centralnej. Pełnomocnictwa udzielane administracji podporządkowanej stanowią dla niej nie tylko podstawę i prawo podejmowania decyzji ale równocześnie obowiązek, tj. administracja podporządkowana może działać jedynie w zakresie w jakim została do tego upoważniona aktami administracji centralnej ale równocześnie jest zobowiązana do bieżącego wykonywania zadań określonych w pełnomocnictwie. Nie może działać z pełną wola ale nie może też być bezczynna", N.M. Korkunow, Russkoje gosudarstwiennoje prawo..., t. II, s. 204. 
tralnym, takim jak Komitet Ministrów, Senat Rządzący i ministrowie, jak i lokalnym - generał-gubernatorom, gubernatorom, naczelnikom miast, a na terenach rdzennej Rosji także organom samorządowym. W konsekwencji, jedynym kryterium pozwalającym na wyodrębnienie aktów stanowionych w trybie administracji podporządkowanej było to, że w odróżnieniu od aktów stanowionych $\mathrm{w}$ trybie administracji centralnej były one warunkowe i ograniczone zakresem udzielonego pełnomocnictwa oraz podlegały zaskarżeniu w przypadku zarzutu naruszenia obowiązującego prawa lub przekroczenia pełnomocnictwa ${ }^{44}$. Zatem w warunkach ustrojowych państwa rosyjskiego, pojęcie administracji podporządkowanej nie było wynikiem przeprowadzenia podziału organów państwa na ustawodawcze i wykonawcze, ale oznaczało jedną z form realizacji władzy najwyższej, zastrzeżonej wyłącznie dla cesarza. Taki stan rzeczy utrzymał się i po $1906 \mathrm{r}^{45}$

Akty prawne stanowione $\mathrm{w}$ trybie administracji podporządkowanej przybierały formę ,postanowień” lub „rozporządzeń obowiązujących” (postanowlenija i rasporiażenija objazatielnyje), „rezolucji” oraz ,instrukcji”46. Upoważnienie do ich wydawania nie wynikało z jakiejś ogólnej zasady, ale przysługiwało poszczególnym organom $\mathrm{w}$ oparciu o indywidualne i szczegółowe pełnomocnictwo zawarte $w$ ich regulaminach i statutach organizacyjnych. W konsekwencji, przepisy określające podstawę, zakres przedmiotowy oraz sposób stanowienia aktów prawnych w trybie administracji podporządkowanej były rozproszone i formułowane w sposób kazuistyczny, co w szeregu przypadków prowadziło do kolizji z regułami ogólnymi stanowionymi w trybie administracji centralnej. W założeniu, wszystkie akty administracji podporządkowanej miały mieć charakter aktów wykonawczych w stosunku do aktów stanowionych w trybie administracji centralnej i w żadnym wypadku nie mogły podważać ich mocy obowiązującej. W praktyce prawo stanowione $\mathrm{w}$ trybie administracji podporządkowanej $\mathrm{w}$ wielu przypadkach nie było z nimi powiązane, a nawet zawierało rozstrzygnięcia sprzeczne z regułami ogólnymi, ustanowionymi w trybie administracji centralnej. Sytuacje takie występowały w szczególności w odniesieniu do postanowień gubernatorów oraz rezolucji wydawanych przez ministrów.

Zgodnie z art. 421 ogólnej organizacji gubernialnej, gubernatorom przysługiwało prawo wydawania postanowień lub rozporządzeń obowiązujących w sprawach dotyczących zachowania spokoju społecznego oraz utrzymania porządku i bezpieczeństwa wewnętrznego na terenie guberni, z zastrzeże-

${ }^{44} \mathrm{~W}$ rzeczywistości, kontrola legalności rozporządzeń, w szczególności ich zgodności z ustawami, była uregulowana jedynie co do rozporządzeń gubernatorów. Zażalenia w tych przypadkach rozstrzygał Senat, Swod Uczrieżdienij Gubiernskich, izdanije 1832, Swod Zakonow, izdanije 1832, t. II, s. 58, art. 274, pkt 4; Swod Uczrieżdienij Gubiernskich, izdanije 1892, Swod Zakonow, izdanije 1892 , t. II, s. 41-43, art. 270-275.

${ }^{45}$ P.E. Kazanskij, op. cit., s. 66-75.

${ }^{46}$ B.M. Koczakow, op. cit., s. 87. 
niem, że „(..) w żadnym wypadku nie mogą one przeczyć ustawom i przepisom prawa karnego oraz postanowieniom władz zwierzchnich" 47 . Jednak równocześnie, według ukazu z 14/26 VIII 1881 r. „O środkach ochrony porządku państwowego i spokoju społecznego”, gubernatorzy uzyskali upoważnienie do: ,(...) stosowania wszelkich środków mających na celu zapewnienie spokojności" ${ }^{48}$. Ten blankietowy charakter pełnomocnictwa udzielonego gubernatorom w sprawach bezpieczeństwa publicznego uprawniał ich do wydawania aktów prawnych zaopatrzonych w sankcje, niezależnie od obowiązujących w tym zakresie ogólnych norm prawa karnego. Pomimo że według ukazu ogłaszającego przepisy z $1881 \mathrm{r}$. miały obowiązywać jedynie przez trzy lata, stale je przedłużano, tak że utrzymały swą moc aż do końca istnienia caratu, chociaż od 1906 r. stały już w jawnej sprzeczności z deklarowaną w Prawach Zasadniczych zasadą legalizmu, obejmującą także akty administracji podporządkowanej ${ }^{49}$. Istnienie tego rodzaju przepisów „wyjątkowych” i teoretycznie „czasowych”, pozwalających organom administracji terytorialnej na tworzenie szczególnych norm prawnych w trybie administracji podporządkowanej, wytworzyło w prawodawstwie rosyjskim rozróżnienie guberni zarządzanych według zasad ogólnych i szczególnych, przy czym te ostatnie, tak jak gubernie Królestwa Polskiego, były z reguły zamieszkane przez ludność nierosyjską ${ }^{50}$.

Innym przykładem swoistej autonomii aktów administracji podporządkowanej, pozwalającej na odstępstwo od reguł ogólnych, były rezolucje ministrów wydawane na podstawie osobistego upoważnienia cesarskiego, udzielonego ministrowi w formie „Najwyższego Rozkazu”, w celu wykonania lub uzupełnienia obowiązującego prawa w konkretnym, zindywidualizowanym przypadku $^{51}$. Oznaczało to przyznanie ministrom prawa stosowania dyspen-

${ }^{47}$ Obszczeje gubiernskoje uczrieżdienije, izdanije 1892, Swod Zakonow, izdanije 1892, t. II, s. 79, art. 421. Także na mocy Najwyżej Zatwierdzonej Uchwały Komitetu Ministrów z 13/25 VII 1876 r. o upoważnieniu miejscowych władz administracyjnych do wydawania postanowień obowiązujących, generał-gubernatorzy, gubernatorzy i naczelnicy miast otrzymali prawo wydawania postanowień, dotyczących porządku policyjnego i bezpieczeństwa publicznego. Jednocześnie pozostawiono osobom prywatnym i stowarzyszeniom prawo zaskarżania takich postanowień na zasadach ogólnych do Senatu, PSZRI 1876, nr 56203, s. 60-62.

${ }^{48}$ Ukaz z 14/26 VIII 1881 r. o środkach ochrony porządku państwowego i spokoju społecznego, PSZRI 1881, nr 350, s. 261-266, art. 1-36.

49 „Postanowienia obowiązujące, instrukcje i zarządzenia wydawane przez Radę Ministrów, ministrów i głównych zarządzających poszczególnymi częściami administracji państwa, a także inne upoważnione do tego przez ustawę polecenia nie mogą przeczyć ustawom”, Osnownyje Zako$n y$, izdanije $1906 \ldots$, s. 9, art. 122.

50 „Cesarstwo Rosyjskie, w stosunku do jego zarządu cywilnego, składa się: 1. z guberni zarządzanych na zasadach ogólnych i 2. z guberni, obwodów i ziem, zarządzanych na zasadach szczególnych", Swod Uczrieżdienij Gubiernkich, izdanije 1832..., s. 1, art. 1; Swod Uczrieżdienij Gubiernkich, izdanije $1892 \ldots$, s. 1, art. 2.

${ }^{51}$, ,...) Nie można uważać za nadużycie władzy przypadku odstąpienia od prawa ogólnego, jeżeli minister posiada w jakiej szczególnej sprawie upoważnienie Władzy Najwyższej”, Uczrieżdienije Ministierstw, izdanije 1892..., s. 237, art. 208. 
sy, a więc nieliczenia się z powszechnie obowiązującymi normami ogólnymi. W codziennej praktyce administracyjnej prawo to definiowano w sposób rozszerzający. Jeżeli urzędnik swoim działaniem złamał ustawowo określoną regułę ogólną, a nie miał upoważnienia do zastosowania dyspensy w tym konkretnym przypadku, to wystarczyło, aby później otrzymał najwyższą aprobatę cesarską sprzecznego z prawem ogólnym aktu administracyjnego i pomimo że działał nielegalnie, był wolny od jakiejkolwiek odpowiedzialności. W taki sposób wszelka niezgodna z prawem działalność urzędów administracji mogła zostać przekształcona $\mathrm{w}$ zgodny $\mathrm{z}$ prawem akt administracyjny w drodze „Najwyższego rozkazu”,52.

VI. Przedstawione wyżej możliwości i sposoby instrumentalizacji procesu legislacyjnego w carskiej Rosji, wynikające bezpośrednio z fundamentalnych zasad ustrojowych tego państwa, powodowały nie tylko niezwykłą mnogość rodzajów aktów prawnych oraz trybów ich stanowienia, ale także trudność skonstruowania przejrzystej hierarchii źródeł prawa. Przy braku formalnej granicy pomiędzy ustawą a rozporządzeniem administracyjnym, hierarchiczne podporządkowanie ukazów ustawom nie mogło być w warunkach ustrojowych państwa rosyjskiego realizowane w logiczny sposób. Niezależnie od tego, czy akty prawne były wydawane bezpośrednio przez monarchę, czy też przez podległe mu organy administracji podporządkowanej, jednakowo były uważane za realizację władzy należącej do samego monarchy. Co prawda, ustawodawstwo rosyjskie znało pojęcie Praw Zasadniczych, które regulowały podstawy ustrojowe państwa, stanowisko prawne i zakres władzy cesarza, a także zawierały przepisy dotyczące stanowienia prawa oraz statuty organizacyjne organów centralnych imperium. Wyodrębniały je wszystkie redakcje pierwszego tomu Zwodu Praw - podstawowej kodyfikacji praw Cesarstwa Rosyjskiego, stanowiącej połączenie systematyzacji tekstów obowiązujących norm prawnych z uwzględnieniem ich nowelizacji. Ale z prawnego punktu widzenia postanowienia Praw Zasadniczych miały tę samą rangę co pozostałe akty prawne rangi ustawowej, zawierające prawa ogólne powszechnie obowiązujące. Stąd też aż do $1906 \mathrm{r}$. nie istniały żadne formalne podstawy do ich wyodrębnienia jako odmiennych źródeł prawa, toteż nie czyniły tego ówczesne systemy rosyjskiego prawa państwowego. Niemniej, w teorii wyróżniano jednak pewne niezmienne i nadrzędne wobec pozostałych prawa zasadnicze, takie jak:

1. zasadę absolutnej władzy cesarza,

2. obowiązek wyznawania przez monarchę wiary prawosławnej,

3. reguły następstwa tronu ${ }^{53}$.

${ }^{52}$ N.I. Łazarewskij, Lekcji po russkomu gosudarstwiennomu prawu, t. I, Sankt Petersburg 1910, s. 45.

${ }^{53}$ A.D. Gradowskij, Naczała russkago gosudarstwiennogo prawa..., s. 9-11; J. Engelman, Das Staatsrecht des russischen Reiches, Freiburg 1889, s. 12. 
Możliwość stworzenia hierarchii rosyjskich źródeł prawa pojawiła się teorii prawa państwowego dopiero po przekształceniach ustrojowych Cesarstwa Rosyjskiego w 1906 r. Wprowadzony wówczas nowy system norm prawnych umieszczał na najwyższym stopniu tej hierarchii Prawa Zasadnicze. Poniżej znajdowały się ustawy zwykle, uchwalane przy łącznym udziale Dumy Państwowej, Rady Państwa i cesarza oraz ukazy z konieczności (ukazy nadzwyczajne), wydawane przez monarchę w okresie przerw pomiędzy sesjami ciał przedstawicielskich, w sprawach należących w normalnych warunkach do parlamentarnej drogi ustawodawczej. Na tym samym stopniu hierarchii aktów normatywnych sytuowane były ukazy cesarskie, stanowione w trybie administracji centralnej w dziedzinach zastrzeżonych do wyłącznej kompetencji reglamentacyjnej monarchy. Najniższy stopnień rosyjskich źródeł prawa stanowiły rozporządzenia i postanowienia wykonawcze, wydawane przez organy aparatu administracyjnego na podstawie delegacji ustawowej w trybie administracji podporządkowanej ${ }^{54}$.

Z pozoru, wprowadzona po $1906 \mathrm{r}$. hierarchia rosyjskich źródeł prawa stanowiła logiczny system, w którym wszystkie ustawy i ukazy wydawane w trybie administracji centralnej miały być zgodne z Prawami Zasadniczymi, a akty wykonawcze administracji podporządkowanej miały opierać się na delegacji ustawowej. Zauważyć jednak należy, że zgodnie z nową redakcją Praw Zasadniczych, inicjatywa ich zmian należała wyłącznie do cesarza, a ich uchwalenie następowało w takim samym trybie, jaki był przewidziany dla ustaw zwykłych, co wyraźnie osłabiało przypisywany im walor praw fundamentalnych. Ponadto, pojęcie ustawy w sensie formalnym zostało zawężone jedynie do aktów prawnych uchwalanych przez Dumę Państwową oraz Radę Państwa i sankcjonowanych przez cesarza. Natomiast poza zakresem przedmiotowym ustawy i sferą kompetencji ustawodawczych ciał przedstawicielskich pozostawała - niemal w niezmienionej postaci - szeroka sfera prawotwórczej działalności administracyjnej zastrzeżona dla cesarza i realizowana w formie ukazów stanowionych w trybie administracji centralnej. Prowadziło to do sytuacji, w której ukaz cesarski wydany w trybie administracji centralnej, poza formą i trybem niczym nie różnił się od ustawy w sensie materialnym. W konsekwencji, Prawa Zasadnicze w redakcji z 1906 r. zachowywały dla cesarza rosyjskiego o wiele większe możliwości prawodawcze niż te, którymi dysponowali monarchowie nawet w takich typologicznie bliskich Rosji państwach jak ówczesne Niemcy, AustroWęgry czy Japonia. Jak zauważał w swoich badaniach Borys E. Nolde:

„(...) jedynie w art. 3 (o języku urzędowym) i art. 69-83 (o prawach i obowiązkach poddanych rosyjskich) jest mowa o tym, że konkretne działania normo-

${ }^{54}$ A.I. Jelistratow, op. cit., s. 55-68; W.M. Gribowskij, op. cit., s. 107-112; B.E. Nolde, op. cit., s. 4-85; N.I. Łazarewskij, op. cit., s. 136; S.A. Kotlarewskij, Juridiczeskije priedposytki russkich Osnownych Zakonow, Moskva 1912, s. 24; N.A. Zacharow, op. cit., s. 286; P.E. Kazanskij, op. cit., s. 676. 
twórcze w tych dziedzinach powinny być realizowane na drodze ustawodawczej. Natomiast pozostałe dziedziny pozostawiono regulacji w trybie ukazowym, $\mathrm{tj}$. w trybie administracji centralnej" $" 55$.

Do tego dodać należy, że wiele dziedzin nie zostało dokładnie rozgraniczonych pomiędzy prawotwórstwo ustawodawcze i ukazowe. W tej sytuacji znaczenia nabierał art. 10 Praw Zasadniczych w redakcji z 1906 r., udzielający cesarzowi generalnego pełnomocnictwa do sprawowania ,władzy administracyjnej w pełnym jej zakresie" oraz dopuszczający w tej mierze interpretację rozszerzającą, zgodnie z którą, „wszystko to, co w dziedzinie administracji nie zostało wyłączone ze sfery władzy monarchy, pozostaje w tej sferze, a każdy wyjątek powinien być omówiony w ustawie osobno" ${ }^{56}$. W praktyce oznaczało to, że podstawowym źródłem rosyjskich przepisów prawnych po 1906 r. pozostawały nadal ukazy cesarskie stanowione w trybie administracji centralnej oraz, posiadające charakter aktów wykonawczych, postanowienia i rozporządzenia wydawane $\mathrm{w}$ trybie administracji podporządkowanej.

\section{CHALLENGES OF IDENTIFYING THE SOURCES OF LAW IN THE LEGISLATION OF THE RUSSIAN EMPIRE}

\section{Summary}

The legislative mechanism of the Russian Empire and related to it types and hierarchy of the sources of law has always been, and continues to be, a controversial issue, giving rise to numerous polemics. This is because the very essence of the autocratic rule in the Russian Empire makes it impossible to accurately distinguish between the legislative and the executive powers. The lack of transparency of the hierarchy of sources of law also means that every attempt the Russian theorists of state and administrative law make to identify and clarify those sources is always deemed to fail. The political transformations of 1906 did not bring any change to the existing system either as no compromise was ever possible in an autocracy in which, despite appearances of legality, the predominant drive was to ensure the integrity of the absolute power of the tsar. The characteristic feature of the legislation in the Russian Empire was its complexity and lack of clarity both with regards to the types and forms of the law sources and the way in which laws were made. As a result, in the all-powerful bureaucratic system of the Russian Empire, laws could be breached, violated or bent with impunity and without observance of any acceptable procedure, merely at the discretion of the sovereign.

\footnotetext{
${ }^{55}$ B.E. Nolde, Oczerki russkago gosudarstwiennogo prawa..., s. 59.

${ }^{56}$ Osnownyje Zakony, izdanije 1906..., s. 1, art. 10.
} 


\title{
LE PROBLÈME DES SOURCES DU DROIT DANS LA LÉGISLATION DE L'EMPIRE RUSSE
}

\begin{abstract}
Résumé
La problématique liée au fonctionnement du mécanisme législatif de l'Empire russe et, ce qui s'en suit, la question quant aux types et hiérarchie des sources du droit ont toujours constitué (et continuent à l'être) des sujets soulevant beaucoup de controverses et la polémique. L'origine de cette situation repose dans la quintessencemême de l'autocratie russe, rendant impossible une séparation juste entre le pouvoir législatif et le pouvoir exécutif et administratif. Par conséquent, elle ne permet pas la création d'un système clair de la hiérarchie des sources du droit, basées sur une distinction entre la loi et le règlement. De ce fait, tous les efforts entrepris par les théoriciens russes du droit étatique et administratif sont condamés d'office à l'échec. Et même en 1906, à l'issue des transformations du système de l'Empire Russe, la situation n'a pas évolué car la tendence dominante à conserver l'aspect incommutable du pouvoir absolu du monarque avec, en parallèle, la création des apparences du légalisme de son fonctionnement, empêchait le compromis durable, vu le régime en vigueur de l'État russe. Par conséquent, le trait caractéristique de la législation russe est sa complexité particulière tant par rapport aux types et formes des sources du droit que par rapport au mode de son institution, la possibilité de violer impunément la loi par la bureaucratie omnipotente ainsi que l'admission des modifications apportées dans la législation en vigueur et dérogations aux règles générales au gré du souverain.
\end{abstract}

